\title{
Áramót eru tímamót
}

Nú hefur nýtt ár, 2017, gengið í garð. Áramót marka upphafið að einhverju nýju og ópekktu. Sumir ætla sér stóra hluti, til dæmis að standa sig betur hvað varðar lífsstíl - léttast, borða grænmeti, hætta að reykja eða hreyfa sig meira. Sem betur fer tekst sumum petta, en ekki nærri öllum.

Í læknadeildinni var mér kennt að pað ætti að nota hvert einasta tækifæri til að messa yfir fólki um heilbrigt líferni. Man sérstaklega eftir orðum hjartalæknis sem sagði: „Við hjartalæknarnir erum miklu betri en lungnalæknarnir í að fá fólk til að hætta að reykja." Ekki er ég viss um að petta standist, en pað er alveg á hreinu að pað verður að grípa sjúklingana pegar peir greinast með alvarlegan sjúkdóm og fræða pá um mikilvægi lífsstílsbreytinga.

Hvað varðar kransæðasjúkdóm eru áhættupættirnir nokkuð vel pekktir. Samkvæmt stórri alpjóðlegri rannsókn, INTERHEART, ${ }^{1}$ standa eftirfarandi áhættupættir fyrir 90\% af áhættunni (population attributable risk): hátt kólesteról (gagnlíkindahlutfall, odds ratio, OR 3,25), reykingar (OR 2,87), streita (OR 2,67), sykursýki (OR 2,37), háprýstingur (OR 1,91) og kviðfita (OR 1,62). Verndandi pættir reyndust vera: hófleg alkóhólneysla (OR 0,91), hreyfing $(\mathrm{OR} 0,86)$ og aukin neysla grænmetis/ávaxta (OR 0,7).

Pegar einstaklingar greinast með kransæðasjúkdóm nota ég tilefnið til að ræða pessa áhættupætti, sérstaklega eftir kransæðavíkkun. Pá eru sjúklingarnir stundum enn á præðingarstofunni. Hjartað er sett upp á risaflatskjá og líkist helst Afríku að stærð. Kransæðarnar sem eru bara nokkrir millimetrar í pvermál eru pá í risastækkun og LAD virkar eins og Nílarfljótið. Ég bendi á staðinn par sem æðin var pröng eða lokuð sem er rót alls ills. Að lokum tek ég stundum upp trompið: litla körfu sem inniheldur blóðsega, árangurinn eftir svokallað „,segasog“. Blóðsegar eru ekki fallegir, virka eins og litlir slepjulegir bleikir ormar og hægt er að sjá á andlitum sjúklinga hversu ógeðfellt peim pykir petta. Ræði svo við sjúklingana um reykingarnar, offituna og svo framvegis. Hins vegar versnar í pví ef ég kemst að pví að sjúklingurinn er reyklaus, vegan maraponhlaupari - pá er körfunni hent í ruslið og ég segi: „Við verðum víst ekki yngri“ eða, ef petta reynist vera ungur einstaklingur: „Petta eru líklega erfðirnar - kannski ætti Decode að rannsaka pig."

Í grein í pessu tölublaði Læknablaðsins ${ }^{2}$ erum við minnt á að kransæðasjúkdómur er ekki eingöngu sjúkdómur aldraða. Greinin fjallar um brátt hjartadrep á Íslandi hjá fertugum og yngri á tímabilinu 2005-2009. Í peirri rannsókn kom í ljós að kransæðasjúkdómur hjá pessum 38 sjúklingum var aðallega sjúkdómur karlmanna (um 84\%) og peirra sem reykja (77\%). Jákvæða ættarsögu höfðu 63\%. Meðalgildi kólesteróls var ekki hátt, 5,1 mmól/l og fjöldi sykursjúkra 9\%. Meðallíkamspyngdarstuðull (BMI) var 29. Einnig var gerður samanburður á tveimur mismunandi tímabilum, 19801984 og 2005-2009, og kom í ljós að dánartíðni hefur lækkað, færri reykja og fleiri fara í kransæðapræðingu á síðari tímabilinu.

Aðrar rannsóknir og birt tilfelli hafa sýnt að pað eru til aðrar óvenjulegar orsakir hjartadreps yngri sjúklinga. Vert er að nefna eftirfarandi: misnotkun kókaíns eða vefaukandi stera, sjúklingar með Factor $\mathrm{V}$ Leiden, Kawasaki sjúkdómur eða rof í kransæð (coronary dissection).

Pó að brátt hjartadrep sé óalgengur sjúkdómur meðal ungs fólks getur hann haft mjög slæmar afleiðingar: valdið örorku, skert lífsgæði og í versta falli leitt til dauða. Pess vegna ættum við læknar að vera á varðbergi og hafa lágan pröskuld að taka EKG og hjartaensím hjá sjúklingi með brjóstverk jafnvel pó að hann sé ungur að aldri. EKG er ódýr, hröð og sársaukalaus rannsókn án fylgikvilla.

Annað sem er mikilvægt og varðar samtalið um lífsstíl og meðferð áhættupátta. Рað væri auðvitað langbest að koma í veg fyrir sjúkdóma í staðinn fyrir að meðhöndla pá pegar peir eru komnir og hafa jafnvel náð að valda varanlegum skaða. Munum hlutverk okkar lækna í forvörnum sjúkdóma. Messum yfir fólki um skaðsemi reykinga og offitu. Náum tökum á blóðprýstingnum, $<140 / 90$ mmHg. Ræðum um mataræði og streitu við skjólstæðinga okkar. Náum markgildum í kólesteróli og sykri með mataræði, eða ef parf, lyfjum. Í mörgum tilfellum snýst petta um endurteknar komur pví erfitt er að koma öllum pessum upplýsingum að í einu stuttu viðtali. Margir purfa skriflegar leiðbeiningar. En takist okkur petta vel erum við að marka tímamót fyrir einstaklinginn sem er mun mikilvægara en nokkur áramót.

Gleðilegt ár!

\section{Heimild}

1. Yusuf PS, Hawken S, Ôunpuu S, Dans T, Avezum A, Lanas F, et al. Effect of potentially modifiable risk factors associated with myocardial infarction in 52 countries (the INTERHEART study): Case-control study. Lancet 2004; 364: 937-52.

2. Magnússon B, Agnarsson U, Porgeirsson G, Guðnason P. Brátt hjartadrep á Íslandi í fertugum og yngri 2005-2209. Samanburður við tímabilið 1980-1984. Læknablaðið 2017; 103: 11-5. 